\title{
$\mathrm{Si}$ 含有 4340 鋼の微細組織と機械的性質に及ぼす \\ 改良オーステンパーの影響十
}

冨田恵之*大川剛 義**

\section{Effects of Modified Austemper on Microstructure and Mechanical Properties of Silicon-Modified 4340 Steel}

by

\author{
Yoshiyuki Tomita* and Takeyoshi OKawA**
}

\begin{abstract}
The effects of the modified austemper (designated MA) on the microstructure and mechanical properties of silicon-modified 4340 steel have been studied with the aim of developing a MA steel for ultrahigh strength applications. The microstructure of the MA steel consisted of triple phases of carbide-free upper bainite, light-tempered martensite and retained austenite. This microstructure was produced by a partial transformation at either 593 or $623 \mathrm{~K}$ for a required time, followed by oil quenching and subsequent tempering at $473 \mathrm{~K}$ after austenitization at $1173 \mathrm{~K}$ (designated 593K-MA, 623K-MA, respectively). Compared to the quenched and tempered steel, the $593 \mathrm{~K}-\mathrm{MA}$ treatment improved the fracture toughness $\left(K_{\mathrm{IC}}\right)$ at high strength level of $2000 \mathrm{MPa}$, owing to an increase in total elongation and also improved the Charpy impact energy. According 623K-MA treatment, its $K_{\mathrm{Ic}}$ was dramatically developed at strength level of $1700 \mathrm{MPa}$, owing to a remarkable increase in total elongation and Charpy impact energy, as compared to the QT steel. Compared to the corresponding conventional austemper treatment, its $K_{\mathrm{IC}}$ becomes significantly increased with a remarkable increase in strength.
\end{abstract}

Key words : Silicon-modified 4340 steel, Modified austemper, Carbide-free upper bainite, Martensite, Morphology and mechanical stability of retained austenite

\section{1 緒言}

中炭素低合金鋼は通常焼入れ後低温焼もどし処理を施 し, 低温焼もどしマルテンサイト組織にして, 高い強度 水準で航空宇宙用輸送機の高性能部材に使用されている. しかし，これら低温で焼もどしされたマルテンサイト組 織は微小き裂に対して極めて敏感で, 使用中にぜい性破 壊, 水素ぜい性あるいは応力腐食割れを引起こしやすい. これら低合金超強力鋼のじん性を改善し, さらには水素 ぜい性や応力腐食割れに対する抵抗を増大させる良策と して，へき開破壊や応力腐食割れに対して高い抵抗をも

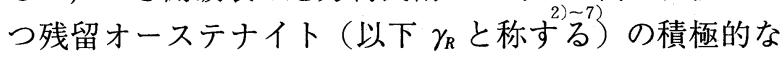
利用があり，近年 Si を添加した低合金超強力鋼のオー ステンパーが注目されている。 これは $\mathrm{Si}$ を添加した低 合金鋼をオーステンパーするとベイナイト変態に伴う未 変態 $\gamma$ 中への炭素濃度が大きくなり, 室温で多量の $\gamma_{R}$ が得られるからであう.

このような観点から前報では Si を添加した 4340 鋼 (以下 $\mathrm{Si}$ 含有 4340 鋼と称する) に593-673K の温度範 囲でオーステンパーを施しその微細組織と機械的性質の 関係を調べた．その結果，(1) 593-623K の温度範囲でオ ーステンパーした場合普通焼入れ焼もどしに比較して破 壊じん性值とシャルピー衝撃值が増加するが, 強度が低 下した；(2) 643-673K の温度範囲でオーステンパーした 場合には塊状の $\gamma_{R}$ が多量に存在するようになり強度が
著しく低下するとともに延・じん性が劣化した；(3) そ のオーステンパー鋼の延・じん性が劣化するのはオース テンパーによって残留する $\gamma_{R}$ が本質的に軟らかいこと とそれが変形中にぜい性的なマルテンサイトに変態しや すいこと, すなわち $\gamma_{R}$ の機械的安定性が悪いことと関 連していることが明らかとなった。

そこで著者らは Si 含有 4340 鋼の強度と延・じん性 のバランスを改善するために，それによって生ずる微細 組織がベイナイト, 焼もどしマルテンサイトおよび $\gamma_{R}$ の三相組織からなる改良オーステンパーを提案した。本 報告では改良オーステンパーによる $\mathrm{Si}$ 含有 4340 鋼の 機械的性質の改善とその改善を支配する微細組織因子に ついて検討した結果を述べる.

\section{2 実 験 方 法}

供試鋼は真空中で誘導溶解後真空中で再溶解した Si 含有 4340 鋼で, その化学成分と Ms 温度は Table I に 示すとおりである.これらの鋼材から機械加工により圧 延方向に対して平行な試験片を切り出し完全焼なましを 行った後試料に供した.

Table II は本実験における熱処理スケジュールを示し たものである.すべての試験片はアルゴンガス気流中で $\gamma$ 化し, オーステンパー処理は鉛-錫浴中で, 焼もどし はシリコンオイルあるいは中性塩浴中でそれぞれ行った

静的引張試験はインストロン万能試験機を使用してゲ

\footnotetext{
$\dagger$ 原稿受理 平成 6 年 5 月 27日 Received May 27, 1994

* 正 会 員 大阪府立大学工学部材料工学科 =593 堺市学園町, Dept. of Metal. \& Mat. Sci., Univ. of Osaka Prefecture, Gakuen-cho, Sakai, 593

** 大阪府立大学大学院 个593 堺市学園町, Graduate Student, Univ. of Osaka Prefecture, Gakuen-cho, Sakai, 593
} 
Table I. Chemical composition (mass \%) and Ms temperature ( $\mathrm{K}$ ) of silicon-modified 4340 steel used.

\begin{tabular}{c|c|c|c|c|c|c|c|c|c}
\hline $\mathrm{C}$ & $\mathrm{Si}$ & $\mathrm{Mn}$ & $\mathrm{P}$ & $\mathrm{S}$ & $\mathrm{Cr}$ & $\mathrm{Mo}$ & $\mathrm{Ni}$ & $\mathrm{V}$ & $\mathrm{Ms}$ \\
\hline 0.41 & 1.70 & 0.80 & 0.006 & 0.0009 & 0.80 & 0.41 & 1.76 & 0.03 & 558 \\
\hline \multicolumn{7}{c}{ Ms temperature was measured by standard dilatometry }
\end{tabular}

Table II. Heat treatment schcdule.

\begin{tabular}{|c|c|}
\hline $\begin{array}{l}\text { Designation } \\
\text { of steel }\end{array}$ & Heat treatment \\
\hline MA & $\begin{array}{l}\text { Austenitize at } 1173 \mathrm{~K} \text { for } 3.6 \mathrm{ks} \text {, transform } \\
\text { isothermally at } 593 \mathrm{~K} \text { for } 740 \text { or } 623 \mathrm{~K} \text { for } 700 \mathrm{~s} \text {, } \\
\text { quench in oil, temper at } 473 \mathrm{~K} \text { for } 7.2 \mathrm{ks} \text {. }\end{array}$ \\
\hline $\mathrm{CA}$ & $\begin{array}{l}\text { Austenitize at } 1173 \mathrm{~K} \text { for } 3.6 \mathrm{ks} \text {, transform } \\
\text { isothermally at } 593 \mathrm{~K} \text { for } 1200 \mathrm{~s} \text { or } 623 \mathrm{~K} \text { for } \\
1000 \mathrm{~s} \text {, cool in oil. }\end{array}$ \\
\hline QT & $\begin{array}{l}\text { Austenitize at } 1173 \mathrm{~K} \text { for } 3.6 \mathrm{ks} \text {, quench in oil, } \\
\text { temper at } 473,573 \text { or } 673 \mathrm{~K} \text { for } 7.2 \mathrm{ks} \text {. }\end{array}$ \\
\hline
\end{tabular}

MA modified austemper; CA conventional austemper ;

QT quench and temper.

ージの長さが $12.5 \mathrm{~mm}$ で, ゲージ断面の形状が $1.5 \mathrm{~mm}$ $\times 4.0 \mathrm{~mm}$ の試験片を用いてひずみ速度 $6.75 \times 10^{-4} \mathrm{~s}^{-1}$ で行った。平面ひずみ破壊じん性 $\left(K_{\mathrm{IC}}\right)$ 試験は標準 CT 試験片を用いて，ASTM 規格 (E-399-72)に準拠して行 い, また $2 \mathrm{mmV}$ ノッチシャルピー衝撃値 $\left(E_{\mathrm{ch}}\right)$ は最大 容量 $49 \mathrm{~J}$ のシャルピー衝撃試験機を用いて求めた。顕 微鏡組織は光学顕微鏡と透過電子顕微鏡により観察した. ベイナイト組織は $5 \%$ ピクラール腐食液で現出させ, ベイナイト体積率は光学顕微鏡による点算法で測定した。 その測定誤差は $\pm 2.5 \%$ であった。 $\gamma_{R}$ の形態は薄膜によ る透過電子顕微鏡 (TEM) で直接観察した。 $\gamma_{R}$ の定量お よびその機械的安定性* (* $\gamma_{R}$ は塑性変形を受けること によってマルテンサイトに変態しやすいがその変態のし 難さの度合を示す）はデイフラクトメーターを用いた $\mathrm{X}$ 線回折法 $\left(\mathrm{MoK} \alpha\right.$ 線, $\mathrm{Zr}$ フイルター) で行った。 $\gamma_{\mathrm{R}}$ の定量に使用した回折面は (200) $\alpha,(211) \alpha,(200) \gamma,(220) \gamma$

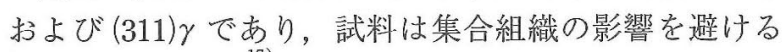
ために回転させだ。后さ機械的安定性を調べるために, 本実験では平行部の長さが $12.5 \mathrm{~mm}$ でその断面形状が $1.5 \mathrm{~mm} \times 10 \mathrm{~mm}$ の試験片を用いて引張試験を行った。 機械的安定性は X 線回折により機械的安定性のパラメ ータである MSA $(\%)=[(3 \%$ あるいは $5 \%$ の引張変形
を受けた試験片の平行部の $\gamma_{R}$ 量)/(同じ試験片の変形の 受けていない頭部の $\gamma_{R}$ 量) $] \times 100$ を求め評価した。

\section{3 実験結果および考察}

\section{$3 \cdot 1$ 微細組織}

Table III に 593 および $623 \mathrm{~K}$ で改良オーステンパー処 理した鋼（以下 $593 \mathrm{~K}-\mathrm{MA}$ および $623 \mathrm{~K}-\mathrm{MA}$ 鋼と称す る), 593 および $623 \mathrm{~K}$ で通常のオーステンパー処理し た鋼（以下 $593 \mathrm{~K}-\mathrm{CA}$ 抢よび $623 \mathrm{~K}-\mathrm{CA}$ 鋼と称する）拉 よび焼入れ焼もどし処理した鋼（以下 QT 鋼と称する） の微細組織の組成を示す。なお，Table IIIに示した結 果は前報で得られたTEM 観察の結果を踏まえたものて ある。この結果から，593K-MA 鋼では炭化物をほとん ど含まない上部べイナイト（以下ベイナイトと称する） (50 vol.\%)，低温焼もどしマルテンサイト（以下マルテ ンサイトと称する) (43 vol.\%) および $\gamma_{R}(7 \mathrm{vol}$ \% \%) から なる三相混合組織を有し，623K-MA 鋼ではベイナイト (50 vol. \%) とマルテンサイト $(40 \mathrm{vol} . \%)$ の基地中に 10 vol.\%の $\gamma_{R}$ が分散する三相混合組織であることが分か る。さらにこれら MA 鋼の組織を光学顕微鏡で観察し た。その結果, 593K-MA 鋼では細長いラス状のベイナ

Table III. Microconstituent of variously heat-treated steels.

\begin{tabular}{c|l}
\hline $\begin{array}{c}\text { Designation } \\
\text { of steel }\end{array}$ & \multicolumn{1}{c}{ Microconstituent } \\
\hline $593 \mathrm{~K}-\mathrm{MA}$ & $\begin{array}{l}\text { Mixed structure of carbide-free upper bainite (50 } \\
\text { vol.\%), light-tempered martensite (43 vol.\%), and } \\
\text { retained austenite (7 vol.\%). } \\
\text { Mixed structure of carbide-free upper bainite (50 } \\
\text { vol.\%), light-tempered martensite (40 vol.\%), and } \\
\text { retained austenite (10 vol.\%). } \\
\text { Mixed structure of carbide-free upper bainite (88 } \\
\text { vol.\%) and retained austenite (12 vol.\%). } \\
\text { Mixed structure of carbide-free upper bainite (82 } \\
\text { vol.\%) and retained austenite (18 vol.\%). } \\
\text { Light-tempcrcd martcnsitic structure containing } \\
\text { little retained austenite. }\end{array}$ \\
\hline
\end{tabular}

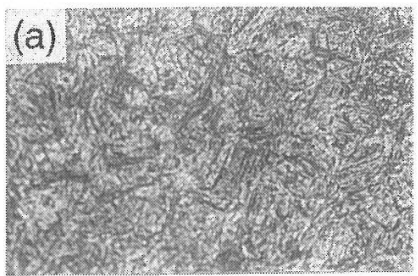

(a) QT steel.

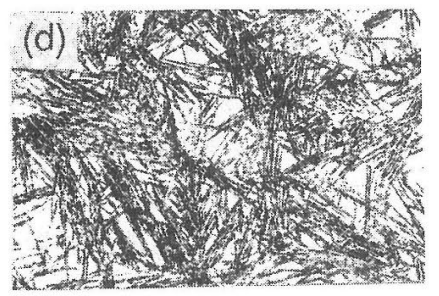

(d) $593 \mathrm{~K}-\mathrm{CA}$ steel.

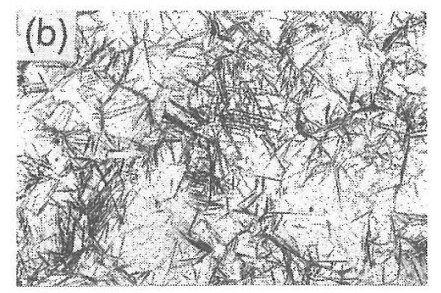

(b) $593 \mathrm{~K}-\mathrm{MA}$ steel

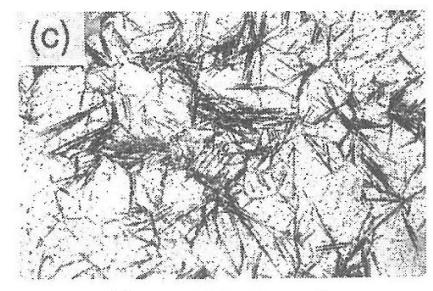

(c) $623 \mathrm{~K}-\mathrm{MA}$ steel.

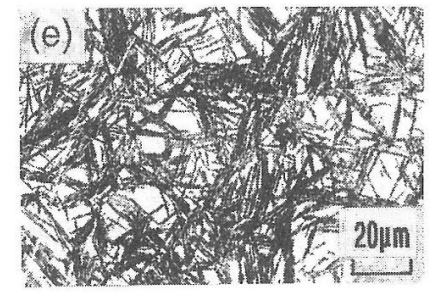

(e) $623 \mathrm{~K}-\mathrm{CA}$ steel.

Fig. 1. Optical micrographs of MA steels (observed in transverse sections). 
イトフェライトがマルテンサイトを微細に分割するよう に現れた(Fig. 1(b))。一方，623K-MA 鋼に和いて生成 するべイナイトフェライトは $593 \mathrm{~K}-\mathrm{MA}$ 鋼に比較してそ の幅がやや大きくなるが，やはりマルテンサイトを微細 に分割した (Fig. 1(c))。593K-CA 鋼ではベイナイト基 地に 12 vol.\% の $\gamma_{R}$ を含む二相混合組織であり（Fig. 1 (d))，623K-CA 鋼ではべイナイト基地に $18 \mathrm{vol} \% \%$ の $\gamma_{R}$ が分散した二相混合組織であった（Fig. 1(e))。QT 鋼で は焼もどし温度にかかわらず $\gamma_{R}$ をほとんど今まない低 温焼もどしマルテンサイト組織であった (Fig. 1(a))。

\section{$3 \cdot 2$ 機械的性質}

Table IV は MA，CA およびQT 鋼の室温における機 械的性質の結果を示したものである。これらの結果は以 下のように要約される。(1) $593 \mathrm{~K}-\mathrm{MA}$ 鋼では QT 鋼に比 較して $2000 \mathrm{MPa}$ の引張強度水準で $K_{\mathrm{IC}}$ が改善される とともに $E_{\mathrm{ch}}$ と破断伸び $(\mathrm{TE})$ が向上した；(2) $623 \mathrm{~K}$ MA 鋼では QT 鋼に比較して強度はやや低いが，1700 $\mathrm{MPa}$ の引張り強度水準で $K_{\mathrm{IC}}$ が著しく改善されるとと もに TEと $E_{\mathrm{ch}}$ が向上した；(3)これら MA 鋼を同じ温 度で変態させた CA 鋼に比較した場合 593 K-MA 鋼の場 合強度と $K_{\mathrm{IC}}$ が著しく改善され，また $623 \mathrm{~K}-\mathrm{MA}$ 鋼の場 合には強度が向上するとともに $K_{\mathrm{IC}}$ と $E_{\mathrm{ch}}$ が著しく改善 された。これら MA 鋼の強度が高いのはマルテンサイ 卜相が適量存在し，かつそのマルテンサイトがベイナイ

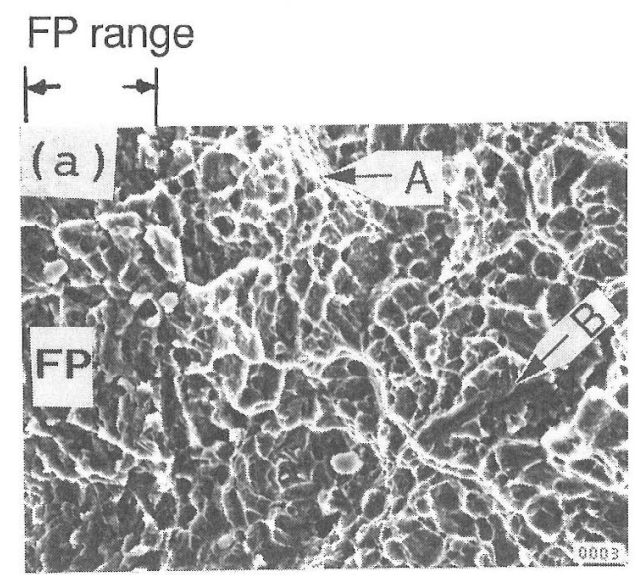

$$
\text { FP range }
$$

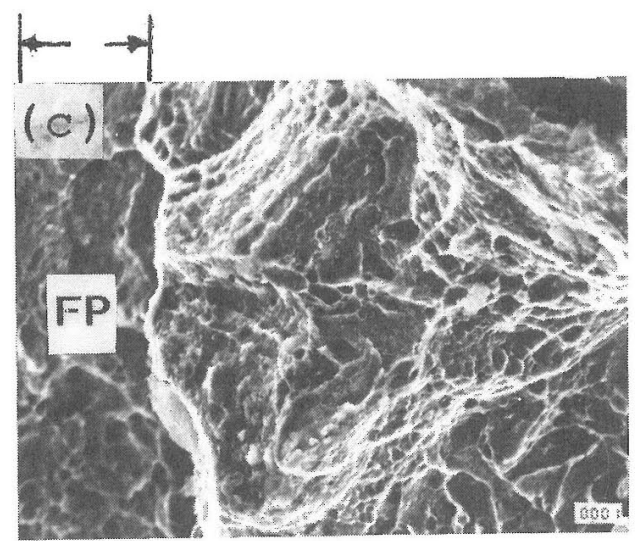

Table IV. Mechanical properties of variously heat-treated steels.

\begin{tabular}{c|c|c|c|c|c}
\hline $\begin{array}{c}\text { Designation } \\
\text { of steel }\end{array}$ & $\begin{array}{c}\sigma_{y} \\
(\mathrm{MPa})\end{array}$ & $\begin{array}{c}\sigma_{u} \\
(\mathrm{MPa})\end{array}$ & $\begin{array}{c}T E \\
(\%)\end{array}$ & $\begin{array}{c}K_{\mathrm{IC}} \\
\left(\mathrm{MPa} \cdot \mathbf{m}^{1 / 2}\right)\end{array}$ & $\begin{array}{c}E_{\mathrm{ch}} \\
(\mathbf{J})\end{array}$ \\
\hline 593K-MA & 1420 & 1990 & 13.5 & 84.5 & 23.8 \\
623K-MA & 1204 & 1700 & 14.9 & 91.8 & 27.8 \\
593K-CA & 1230 & 1610 & 17.5 & 72.5 & 27.0 \\
623K-CA & 1010 & 1320 & 16.5 & 73.8 & 28.4 \\
473K-QT & 1600 & 1950 & 7.8 & 62.3 & 17.1 \\
573K-QT & 1600 & 1950 & 10.9 & 68.1 & 20.4 \\
673K-QT & 1430 & 1705 & 11.5 & 71.6 & 22.1 \\
\hline
\end{tabular}

$\sigma_{y}: 0.2 \%$ offset yield stress; $\sigma_{u}:$ ultimate tensile strength;

$T E$ : total elongation; $E_{\mathrm{ch}}$ Charpy impact energy.

トによって有効的に細分化されたことによるものと考え られる。一方, 延・じん性の改善は MA 鋼に存在する $\gamma_{R}$ の形態に強く依存するものと思われる。

\section{$3 \cdot 3$ フラクトグラフィ}

MA 処理によって延・ビん性が改善される理由を明ら かにするために MA 鋼の $K_{\mathrm{IC}}$ 試験後の予き裂直下の破 面を QT 抢よび CA 鋼の破面と比較して観察した。そ の結果次のことが分かった。(1) QT 鋼の予き裂直下で はデインプル破面（知印 A) と擬へき開破面（矢印 B) の混合からなっていた (Fig. 2(a))；(2) MA 鋼の予き裂 直下では $\gamma_{R}$ のき裂鈍化あるいはき裂ブランチング効果 によって生じたと思われる微細なデンプル破面あるいは 著しく隆起した破面が多く観察された（Fig. 2(b) 抢よび
FP range

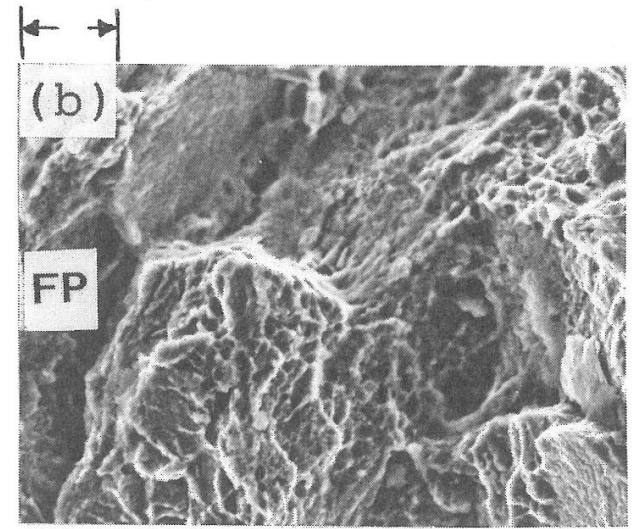

FP range

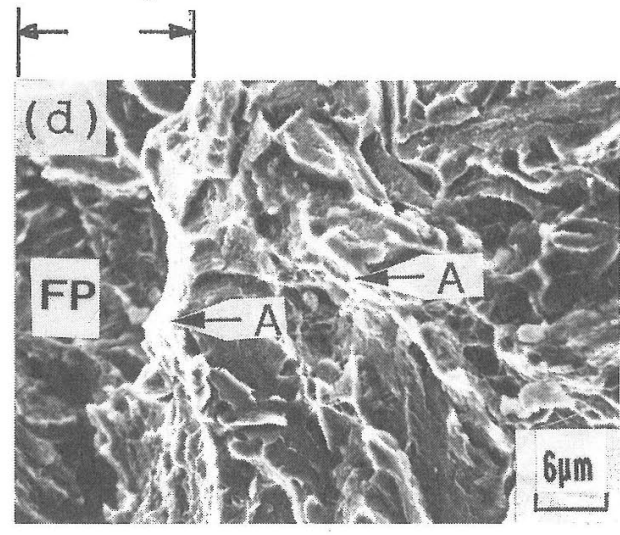

(a) QT steel. (b) 593K-MA steel. (c) 623K-MA steel. (d) 593K-AT steel. FP indicates fatigue precrack. Arrows $A$ and $B$ indicate dimple and quasi-cleavage fatigue surface.

Fig. 2. SEM fractographs of CT specimens. 
(c)）；(3) CA 鋼の予き裂直下ではベイナイトブロックの 大きさに相当する破面が見られるとともに，予き裂と破 面の境界や棈成されている個々の破面の境界に带状の ディンプル（知印A）が観察された (Fig. 2(d))。これ らの結果から MA 鋼における延・じん性の改善には $\gamma_{R}$ が大きく貢献し，かつその機械的安定性に強く依存する ことが示唆された。

\section{$3 \cdot 4$ 改良オーステンパー鋼の $\gamma_{R}$ の機械的安定性}

MA 鋼に存在する $\gamma_{R}$ の機械的安定性を調べるため安 定性のパラメータである MSA 值を求めその結果を Table V に示した。なお， Table Vには比較のため CA 鋼の MSA 值の結果も同時に示した。その結果以下のこ とが分かった。(1) CA 鋼に $3 \%$ ひずみを加えた後の $(\mathrm{MSA})_{3}$ \% 值は変態温度にかかわらず約 $60 \%$ であるが, MA 鋼における $(\mathrm{MSA})_{3} \%$ 值は変態温度にかかわらず約 $90 \%$ の高い值を示した。さらに $5 \%$ ひずみを加えた $\mathrm{CA}$ 鋼の $(\mathrm{MSA})_{5} \%$ 值は変態温度にかかわらず約 $40 \%$ に 低下するが MA 鋼の $(\mathrm{MSA})_{5 \%}$ 值は変態温度にかかわら ず約 $80 \%$ の高い值を示した。

\section{3・5 改良オーステンパー鋼の $\gamma_{R}$ の形態}

上述の結果から MA 鋼の延・ビん性が優れているの は MA 鋼に存在する $\gamma_{R}$ の機械的安定性がきわめて高い ことによることが示唆された。そこで、MA 鋼中に存在
Table V. Mechanical stability of retained austenite of variously heat treated steels.

\begin{tabular}{c|c|c}
\hline $\begin{array}{c}\text { Designation } \\
\text { of steel }\end{array}$ & $(\text { MSA })_{3} \%$ & $(\text { MSA })_{5 \%}$ \\
\hline 593K-MA & 90.8 & 82.5 \\
623K-MA & 89.9 & 81.2 \\
593K-CA & 60.5 & 40.9 \\
623K-CA & 59.1 & 40.3 \\
\hline
\end{tabular}

(MSA) $3 \%$ and (MSA) $5 \%$ are percent ratio of retained austenite content of gauge length to retained austenite content on head of tensile specimens after 3 and $5 \%$ uniaxial plasticdeformation, respectively.

する $\gamma_{R}$ の機械的宏定性がなぜ高いのかを明らかにする ために MA 鋼を $3 \%$ 塑性変形させた後残留している $\gamma_{R}$ の形態をTEM で観察した。その結果， $3 \%$ 変形させ た MA 鋼中に存在する $\gamma_{R}$ の形態は基本的に三つの夕イ プからなることが分かった。 その代表的な結果を Fig. 3 〜 5に示した。すなわち，第一の夕イプはベイナイト フェライトの境界に残留する薄膜状の $\gamma_{R}$ である (Fig. 3 (b)において矢印で示す)。この種の $\gamma_{R}$ は炭素濃度が高 い上に周囲の比較的剛性のあるべイナイトに拘束されて いるため厳しい変形を受けてもマルテンサイトに変態せ ず高い機械的安定性を示し，鋼の延・じん性の向上に貢 献するものと考えられる。第二の夕イプはマルテンサイ 卜のラス境界に存在する薄膜状の $\gamma_{R}$ である (Fig. 4 (b)
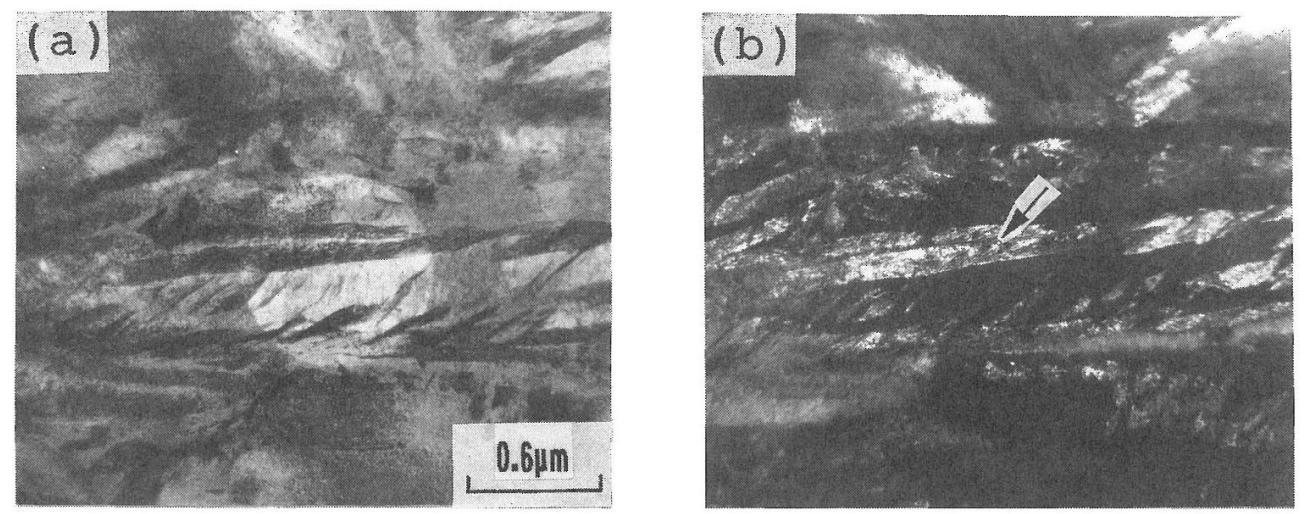

(a) Bright field image; (b) Dark field image of $002 \gamma$ diffraction spot. Incident beam direction is $[100] \gamma$. Arrow indicates $\gamma_{R}$.

Fig. 3. TEM micrographs after $3 \%$ plastic deformation of $623 \mathrm{~K}-\mathrm{MA}$ steel (observed in tranverse section).
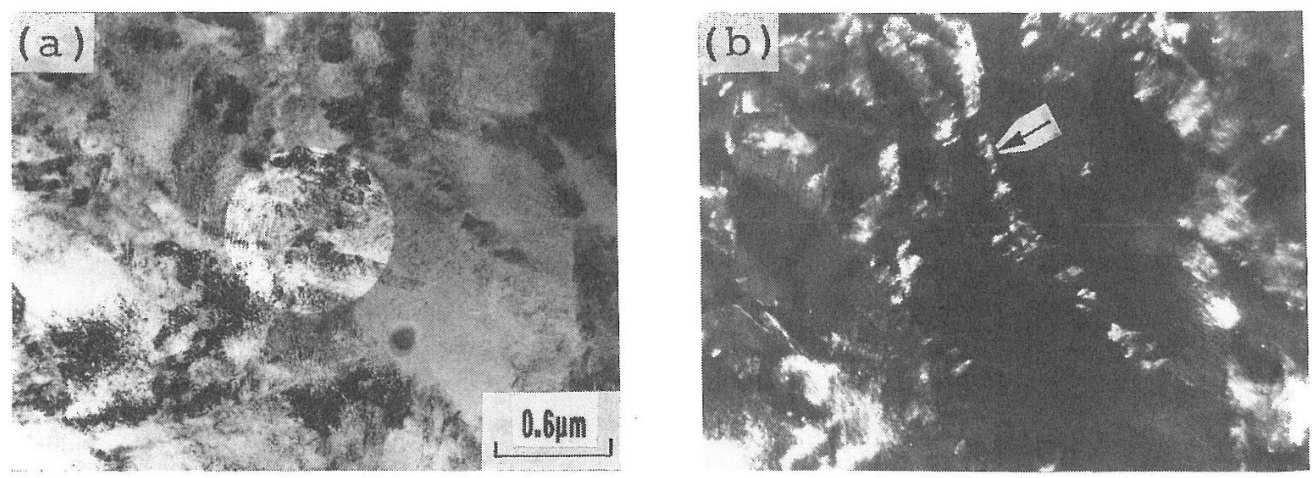

(a) Bright field image. (b) Dark field image of $200 \gamma$ diffraction spot. Incident beam direction is $[111] \alpha$. Arrow indicates $\gamma_{R}$.

Fig. 4. TEM micrographs after $3 \%$ plastic deformation of $623 \mathrm{~K}-\mathrm{MA}$ steel (observed in transverse section). 

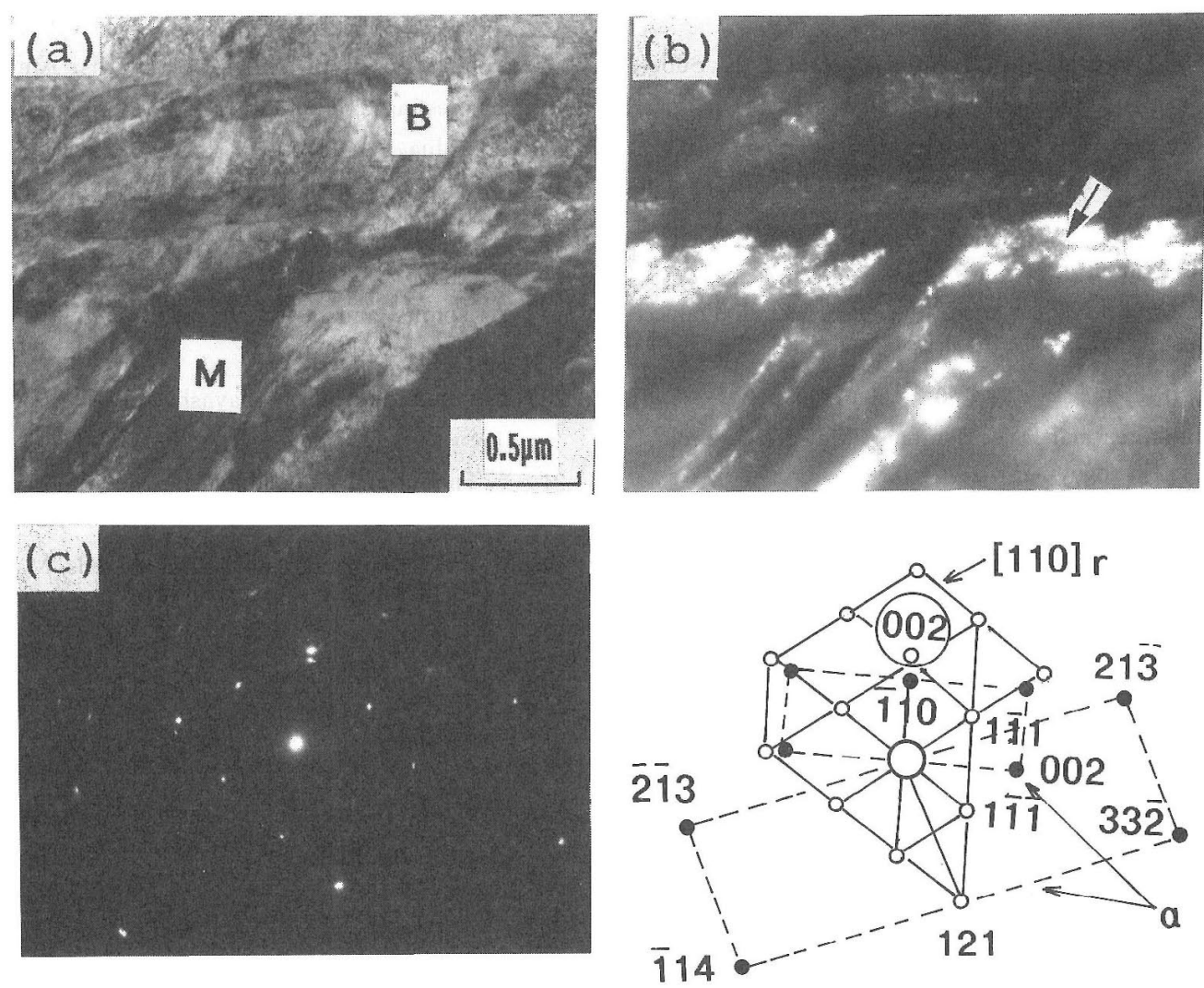

(a) Bright field image. (b) Dark field image using $200 \gamma$ diffraction spot in (c) M and B show martensite and bainite, respectively. Arrow indicates $\gamma_{R}$.

Fig. 5. TEM micrographs after $3 \%$ plastic deformation of $623 \mathrm{~K}-\mathrm{MA}$ steel (observed transverse section).

において矢印で示す)。この $\gamma_{R}$ は第一の夕イプの $\gamma_{R}$ よ り炭素濃度が低いがベイナイトより剛性のあるマルテン サイトに束縛されているため変形によってマルテンサイ 卜に変態し難く，鋼の延・じん性の改善に大きく寄与す ることが報告されている. 第三のタイプはマルテンサイ トのパケットとベイナイトのパケットの間に存在する不 規則な形状をもつ $\gamma_{R}$ である（Fig. 5 (b)において矢印で 示す).この種の $\gamma_{R}$ はベイナイトとマルテンサイトが隣 接しているため上述の第二のタイプの薄膜状の $\gamma_{R} よ り$ 塑性拘束度はやや劣るが，ベイナイトに隣接しているた め第二の夕イプの $\gamma_{R} よ り$ 炭素濃度は高いと考えられる。 それ故, 前二者之同様この $\gamma_{R}$ も機械的安定性が高く鋼 の延・じん性の向上に大きく貢献するものと考えられる。

以上の結果から，改良才ーステンパーした Si 含有 4340 鋼の機械的性質が優れているのは炭化物をほとん ど含まない針状のベイナイト相とそのベイナイトによっ て微細に分割されたマルテンサイト相が適量存在し，か つその基地中にきわめて機械的安定性の高い独特な形態 をもつ $\gamma_{R}$ が分散していることによると結論される。

$$
4 \text { 結 論 }
$$

改良オーステンパー (MA) した Si 含有 4340 鋼の微細 組織と機械的性質について検討し，以下のような結果を 得た。

(1) MA は $1173 \mathrm{~K}$ で $\gamma$ 化後 593 あるいは $623 \mathrm{~K}$ のベ イナイト変態温度域で部分変態させた後油焼入れし, 続 いて低温焼もどし処理をする熱処理で，その微細組織は
炭化物をほとんど含まない上部ベイナイト，低温焼もど しマルテンサイト执よ゙ $\gamma_{R}$ の三相からなっている。

(2) 593K で MA 処理した鋼 (593K-MA 鋼) では焼入 れ後 $573 \mathbb{K}$ で焼もどし処理した鋼に比較して $2000 \mathrm{MPa}$ の引張強度水準で $K_{\mathrm{IC}}$ が改善されるとともにシャルピー 衝撃㑑と破断伸びが们上した。

（3） $623 \mathrm{~K}$ で MA 処理した鋼 (623K-MA 鋼) の場合焼 入れ後 673K で焼もどし処理した鋼に較べて $1700 \mathrm{MPa}$ の引張り強度水準で $K_{\text {IC }}$ が著しく改善されるとともに シャルピー衝撃值と破断伸びが向上した.

(4)これら MA 鋼は同じ温度で変態させた通常の才 ーステンパー処理鋼に比較して強度が顕著に向上すると ともに $K_{\text {IC }}$ が著しく改善された。

(5) 微細組織の観察, フラクトグラフィ，X 線回折 の結果からっこれら MA 鋼の機械的性質が優れている のは針状のベイナイト相とそのベイナイトによって微細 に分割されたマルテンサイト相が適量存在し，かつその 基地中にきわめて機械的安定性の高い独特な形態をもつ $\gamma_{R}$ が分散していることによることが結論された。

最後に本実験にご協力下さった川崎製鉄 (絑) 製鋼技術 研究所に感謝の意を表します。

\section{参考文 献}

1 ) 冨田恵之, 材料, 40, 133 (1991).

2) D. Webster, Trans. ASM, 61, 816 (1968).

3) H. W. Hayden and S. Floreen, Trans. ASM, 61, 474 
(1968)

4 ) W. Beck, J. O. Bockris, M. A. Genshaw and P. K. Subramanyan, Metall. Trans., 2, 883 (1971).

5 ) R. A. McCoy and W. W. Geberich, Metall. Trans., 4, 539 (1973).

6 ) R. O. Ritchie, M. H. C. Cedeno, V. F. Zackay and E. R. Parker, Metall. Trans. A, 9, 35 (1978).

7) T. V. Venkatasubramanian and T. J. Baker, Metall. Trans. A, 11A, 200 (1980).

8 ）篠田研一, 山田利郎, 熱処理, 20, 326 (1990).

9 ) V. T. T. Miihkinen and D. V. Edmonds, Mater. Sci. Technol., 3, 431, 441 (1987).

10). 沢井 嚴, 内田尚志, 熱処理, 30, 27 (1990).

11）松村 理，佐久間康治，武智 弘，鉄と鋼， 77, 1304 (1991).

12) K. Tsuzaki, C. Nakao and T. Maki, Mater. Trans. JIM, 32, 658 (1991).

13) S. J. Matas and R. F. Heheman, Trans. Metall. Soc. AIME, 221, 179 (1961)

14) H. K. D. H. Bhadeshia and D. V. Edmonds, Met. Sci., 17, 411, 420 (1983).
15）富田恵之, 大川剛義，材料， 43，509（1994）.

16) Annual Books of ASTM Standards, American Society for Testing and Materials, ASM Standards E23-72, Philaderphia, PA, 1972.

17) R. L. Miller, Trans. ASM, 61, 592 (1968).

18) Y. Tomita and K. Okabayashi, Metall. Trans. A, 14A, 485 (1983)

19) Y. Tomita and K. Okabayashi, Metall. Trans. A, 14A, 2387 (1983).

20) Y. Tomita and K. Okabayashi, Metall. Trans. A, 16A, 73 (1985).

21) Y. Tomita and K. Okabayashi, Metall. Trans. A, 16A, 83 (1985)

22) V. T. T. Miihkinen and D. V. Edmonds, Mater. Sci. Technol., 3, 422 (1987)

23) B. V. N. Rao and G. Thomas, Metall. Trans. A, 11A, 441 (1980).

24) M. Sarikaya, B. G. Steinberg and G. Thomas, Metall. Trans. A, 13A, 2227 (1982).

25) J. J. Yi, K. J. Yu, I. S. Kim and S. J. Kim, Metall. Trans. A, 14A, 1497 (1983) 